\title{
Atlantisk reform skal være en pakkeløsning
}

Hans Mouritzen

\section{De store udvidelser af EU og NATO nødvendig- gør en atlantisk institutionel reform. Der er imid- lertid ikke behov for nye atlantiske institutioner, men for en tilpasning af de eksisterende}

De atlantiske relationer, især USA's forhold til kontinental-Europa, nåede et lavpunkt i forbindelse med den USA-ledede operation mod Irak. Den havde intet klart FN-mandat, og kun nogle få europæiske allierede tilsluttede sig den amerikanske krigsindsats. Siden da, og især fra 2005, er relationerne gradvist blevet forbedrede igen. Politisk vilje i retning heraf synes i dag at være til stede på begge sider af Atlanterhavet. Der er imidlertid ingen garanti for, at et "nyt Irak" kan undgås.

Med henblik på at forbedre relationerne generelt og samtidig tage de stedfundne udvidelser af nøgleinstitutioner som NATO og EU i betragtning har tænketanke på begge sider af Atlanterhavet præsenteret adskillige forslag. Nedenfor præsenteres og syntetiseres nogle af de bedste institutionelle reformforslag. Min po- inte er, at de skal være politisk balancerede - dvs. "pakkeløsninger" i forhold til de vigtigste euro-atlantiske aktører for at være realistiske. Forslagene er også, i modsætning til de fleste tænketanksforslag, integreret i en helhedsforståelse af international politik og internationale institutioners rolle heri. Læseren kan være uenig i forudsætningerne, men de er i hvert fald gjort eksplicitte i det følgende.

Ingen tænketank- eller andre reformforslag er p.t. sat i værk. NATO har igangsat et internt reformarbejde, som måske fører til resultater på Riga-topmødet i juni 2006. Samtidig befinder reformforslag vedrørende det bilaterale forhold EU-USA sig i venteposition på grund af EU's forfatningskrise og "tænkepause". Det atlantiske afventer kort sagt, at EU bringer orden i eget hus. 


\section{Behovet for atlantiske institutioner}

Atlantiske institutioner kan kun gøre gavn, hvis der er vilje til dialog på begge sider af Atlanterhavet. Institutionerne kan ikke erstatte den fornødne politiske vilje. Men de kan være et vigtigt middel til at opretholde en euro-atlantisk forståelse, eller endog symbiose, når den én gang er etableret. De sikrer muligheden for dialog på såvel politisk topniveau som på forskellige embedsmandsniveauer (undertiden også på parlamentarisk niveau).

En euro-atlantisk "symbiose" er ikke så idyllisk, som ordet kunne antyde. Den er baseret i alt væsentligt på et skrøbeligt Paris-London kompromis om atlantiske relationer. Ifølge dette er Europa hverken så atlantisk, som briterne foretrækker, eller så uafhængigt som franskmændene vil have. Symbiosen herskede efter den Kolde Krig, indtil den begyndte at svigte alvorligt i 2002 under opsejlingen til Irak-krisen. Med starten på præsident Bushs anden periode $\mathrm{i}$ 2005 forekom det imidlertid, at de væsentligste aktører på begge sider af Atlanterhavet gjorde sig klar til at starte forfra. Ikke mindst præsident Bushs symbolske besøg i EU-institutionerne i Bruxelles i februar 2005 (det første besøg af en amerikansk præsident) syntes at bane vejen for en ny symbiose.

Spørgsmålet er så, om man politisk og institutionelt blot kan lade som om intet var hændt og starte, hvor man slap omkring midten af 2002? Er institutionel reform eller endog nyskabelse virkelig nødvendigt? Svaret er ja. En tilbagevenden til det gamle er af flere grunde umulig. Mega-udvidelserne af EU og NATO (fuldbyrdet 2004), de to nøgleinstitutioner for euro-atlantiske relationer, har betydet, at mange flere europæiske aktører ønsker at blive hørt i den atlantiske dialog. Dette giver nogle aggregerings- og repræsentativitetsproblemer, som kun kan løses gennem en eller anden form for institutionel tilpasning.

Hertil kommer, at der er påtrængende behov for uformelle strategiske diskussioner på tværs af Atlanterhavet: om betingelserne for brug af magt (bortset fra selvforsvar) og de bedste midler til fremme af demokrati og retssamfund. Dette indbefatter en fælles forståelse af terrorismens rødder og dens forebyggelse på længere sigt. Naturligvis kan disse emner diskuteres ad-hoc i hver enkelt krisesituation. Men det vil stabilisere en symbiose, hvis man har nærmet sig enighed i disse hovedspørgsmål på det generelle plan, befriet fra en konkret situations særlige hensyn og tidspres. En sådan tilnærmelse forudsætter, at egnede dialogkanaler er til stede.

I tillæg kommer et behov for en atlantisk "high politics" arbejdsdeling, både en geografisk og en funktionel. Den kunne fx indebære, at EU tog sig af sit naboskab fra Barentshavet til Marokko sammen med USA 
og USA af resten. At EU lagde vægten på "soft power" og USA på "hard power" (som tendensen de facto allerede er). Sådanne sensitive emner kræver uformel, strategisk og diskret dialog. Også til dette formål kræves velfungerende atlantiske kanaler. Som vi skal se i næste afsnit, har det ikke skortet på atlantiske reformforslag efter Irak-konflikten.

\section{Reformdiskussioner efter Irak}

Atlantiske kommentatorer har været enige om to ting. For det første at Irak var en atlantisk fiasko, og for det andet at denne fiasko ikke bør gentages. Anbefalinger for at undgå det- te har imidlertid været ganske forskelligartede. Blandt konservative kommentatorer i USA forkastede nogle få NATO og anbefalede i stedet stærke bilaterale bånd til Amerikas "virkelige venner" i Europa, såsom Storbritannien, Danmark og Polen (jf. figur).

De vigtigste konservative tænketanke (Heritage Foundation m.fl.) har dog foreslået, at NATO forbliver den essentielle atlantiske organisation, idet man dog samtidig lægger det meste af skylden for fejltagelserne i det forgangne på europæernes mangel på " $ø$ konomisk og militær solidaritet" (byrdefordeling). Mange amerikanske tænketanke (German

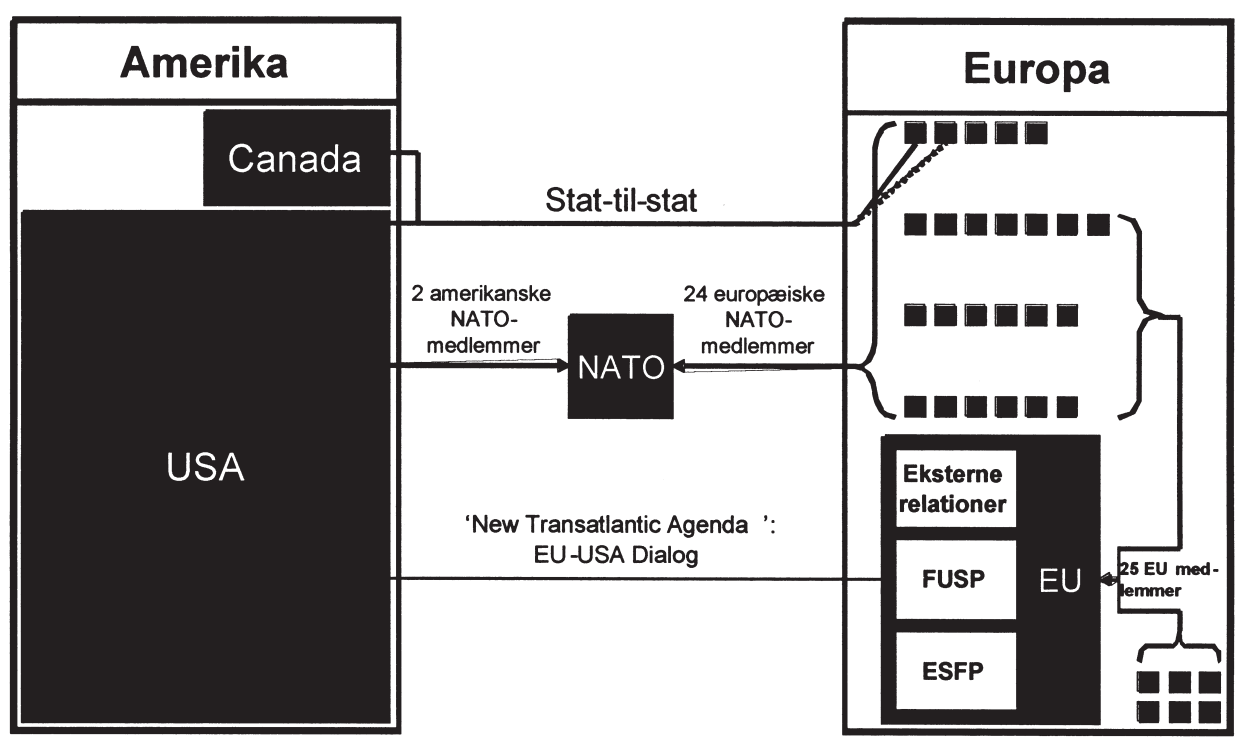

Fig. Det atlantiske samarbejdes hovedkanaler. 
Marshall Fund, CSIS, m.fl.) har, ikke desto mindre, sammen med europæiske (Centre for European Reform, EU Institute for Security Studies, m.fl.) betonet EU-USA dialogen som den vigtigste kanal til afklaring af fremtidig fælles stategi.

Denne betoningsforskel - NATO vs. EU-USA dialogen - vidner om tænketankenes forskellige opfattelser af EU, især ønskeligheden af EU som en fuldgyldig sikkerhedspolitisk aktør. Hvis dette ønskes, skal EUUSA kanalen logisk være den vigtigste kanal for atlantisk dialog. Hvis ikke, skal NATO have prioritet.

Som aldrig før kom disse forskellige opfattelser for dagens lys i forbindelse med EU's forfatningskrise i det sene forår 2005. De konservative tænketanke frygtede, at et styrket EU med ratificeret forfatningstraktat ville svække USA's indflydelse i Europa. De triumferede diskret, da franskmændene stemte nej. Andre tænketanke betonede imidlertid, at ratifikationsfiaskoen også var et amerikansk nederlag.

Også blandt officielle statsrepræsentanter kom atlantisk reform i fokus. Den 12. februar 2005 leverede den tyske forsvarsminister Struck en tale på vegne af den sygemeldte forbundskansler Schröder til den traditionelle München-konference om sikkerhedspolitik:

"NATO er ikke længere det primære sted, hvor atlantiske partnere diskuterer og koordinerer strategier. Det samme gælder for USA-EU dia- logen, som i sin nuværende form hverken yder retfærdighed til Unionens voksende betydning eller til de nye krav til atlantisk samarbejde."

For at forbedre det atlantiske samarbejde blev det foreslået, at et panel af uafhængige eksperter fra begge sider af Atlanterhavet skulle oprettes for at bistå med at finde en løsning på de atlantiske institutionelle problemer. Panelet skulle levere en rapport til statsoverhoveder og regeringsledere i NATO og EU ved begyndelsen af 2006.

Talen vakte en hel del opmærksomhed og en flerhed af reaktioner fra regeringer og kommentatorer. Nogle så det som et skridt mod at nedlægge NATO. Kansleren stod ved sine synspunkter dagen efter med understregning af vigtigheden af det transatlantiske partnerskab. Udenrigsminister Joschka Fischer følte behov for at understrege, at Schröders ærinde var at revitalisere NATO, ikke at nedlægge det.

Forudsigeligt nok støttede Frankrigs præsident Chirac Schröders reformtanke, med understregning af den nye og voksende rolle til EU. Panelforslaget var faktisk blevet fremført i tilsvarende form af den franske udenrigsminister nogle måneder forinden. Den amerikanske administration, der ikke var blevet briefet på forhånd om udspillet, reagerede instinktivt negativt ved at bakke op om NATO som hjørnestenen i de atlantiske relationer. "NATO besidder en hel del energi og vi- 
talitet" ifølge forsvarsminister Rumsfeld. Paradoksalt nok var dette netop tidspunktet, hvor USA's præsident havde besluttet at opgradere EU i sin Europa-politik, som illustreret af hans besøg i EU-institutionerne i Bruxelles omkring en uge efter. Noget tyder på, at hans administration havde planlagt at fremkomme med specifikke reformforslag, når EU forventeligt havde ratificeret sin forfatningstraktat.

NATOs generalsekretær, de Hoop Scheffer, afviste kanslerens udspil. Han understregede imidlertid, at "NATO skal blive et mere politisk forum." Der var og er interne NATOreformplaner undervejs (under ledelse af den danske ambassadør Jesper Vahr, hvis anbefalinger ventes diskuteret på NATOs Riga-topmøde i juni 2006). Kanslerens appel om bredere reform er imidlertid ikke blevet fulgt op. EU-USA aspektet ved atlantisk reform er p.t i et dødvande som følge af EU's tænkepause. Den ny tyske kansler Angela Merkel har flere gange erklæret, at NATO skal blive mere synlig som politisk alliance. Hvad dette betyder mere konkret, fx i reformøjemed, er dog p.t. stadig uklart.

\section{IGO'er som "slyngplanter"}

Internationale institutioner tilskrives en meget beskeden rolle i realistisk eller geopolitisk teori. Opfattelsen i nærværende sammenhæng er, at deres rolle er beskeden, men på en ganske finurlig måde. IGOer (internationale regeringsinstitutioner) ses som "slyngplanter". For det første er de svage (kan ikke holde sig oppe uden støtte), for det andet er de smukke (tjener dekorative formål), og for det tredje er de næsten umulige at slippe af med. Deres svaghed er mest udtalt i "high politics", typisk sikkerhedspolitik.

Hvordan kan disse svage skabninger være så vanskelige at slippe af med? Simpelthen fordi de stærkeste aktører i international politik, nationalstaterne, ønsker at de skal overleve, selv hvis de skulle være overflødige eller ineffektive i forhold til deres officielle formål. IGOerne tjener typisk visse latente nationale interesser som følge af deres blotte eksistens; derfor bliver de sjældent eller aldrig nedlagt. På den ene side tillader nationalstaterne ikke IGOerne at blive for indflydelsesrige - især ikke i "high politics". På den anden side tillader de dem ikke at forsvinde.

Eksempler på nationale latente interesser kunne være IGOer som ansigtsredder for en stormagt, legitimitetsreservoir (mest FN), nødudgang (hvis en anden IGO viser sig at være blokeret) eller redskab til afhængighedsspredning. For blot at give en enkelt illustration, blev NATO oprettet til at imødegå og afskrække et sovjetisk militært angreb på Vesteuropa. Imidlertid fandt de mindre medlemslande hurtigt ud af, at NATO også var et glimrende red- 
skab til at sikre afhængighedsspredning i selve Vesteuropa, dvs. undgå at de blev for ensidigt afhængige af en bestemt europæisk stormagt. De kunne sprede deres afhængighed på flere stormagter, herunder den amerikanske supermagt. Dette forbedrede naturligvis deres indflydelsesmuligheder.

Med andre ord kan IGOer være nyttige for stater på mere raffinerede måder end dem, der følger af IGOernes officielle formål eller officielle retorik. Dette har sjældent været tilsigtet fra IGOens fødsel; det har enten været en sidegevinst eller helt uforudset. Ved begivenhedernes sammentræf er nytten imidlertid blevet "opdaget" af staterne. Ved de facto at være gavnlige for en eller flere stormagter sikres IGOernes overlevelse. Deres levedygtighed er næppe resultatet af deres egen bureaukratiske træghed.

Som nævnt er (high politics) IGOer så svage som institutioner, at de har meget lidt bureaukratisk styrke og træghed at støtte sig til. For eksempel var NATO-bureaukratierne (den civile "Internationale Stab" og den sekonderede militære stab) ikke stærke nok til at sikre deres egen overlevelse og "task expansion" (opgave-udvidelse) efter den Kolde Krig, da deres oprindelige opgaver mere eller mindre forsvandt sammen med Sovjetunionen. Kun nationale myndigheder, dvs. USA og de atlantisk orienterede stater i Europa, var stærke nok til at gøre det.
Det er helt i overensstemmelse med dette statscentrerede perspektiv, at de "elektriske pærer" i de internationale institutioner går ud næsten samtidig, når en symbiose bryder sammen. I forbindelse med Irak-krigen, for eksempel, blev NATO, EU (FUSPen, den fælles udenrigs- og sikkerhedspolitik), FN's Sikkerhedsråd og sågar det nordiske udenrigspolitiske samarbejde mere eller mindre lammet (men ikke nedlagt, naturligvis). Der var ikke noget reserveaggregat, endsige nødbatterier, i nogen af dem.

Med denne opfattelse af sikkerheds-IGOer har nationalstater hver deres favoritinstitution. Dette betyder ikke, at rivaliserende stater forlader en sådan institution; de nedtoner bare deres profil. At forlade den ville være for stærkt et signal at sende; det ville føre til mulig gengældelse fra anden side og derfor måske en nedmontering af hele IGOsystemet. Frankrig forlod fx ikke USA's favoritorganisation, NATO, i 1960'erne, men kun den militære struktur (og dele af det militære samarbejde med USA blev fortsat på anden vis).

Hvad der kan tage sig ud som institutionelle territorieslagsmål viser sig ofte at bunde i nationale rivaliseringer. Den nylige konflikt mellem NATO og EU om, hvem der skulle bistå den Afrikanske Union med en luftbro og anden støtte til Darfur (Sudan), viste sig i virkeligheden at bunde i en uenighed mellem Wash- 
ington og Paris om Europas forsvarspolitiske ambitioner. Hvilke opgaver skulle udføres af NATO og hvilke af ESFP (den europæiske sikkerheds- og forsvarspolitik)? Involveret i dette spørgsmål er måske også indflydelsessfærer. Skal Afrika konsolideres som europæisk/fransk sfære snarere end som angelsaksisk? Som udtrykt af en fransk diplomat, "EU har været i Darfur længe før NATO".

Med ovenstående forudsætninger om internationale institutioner er de først og fremmest statsinstrumenter. Hvorvidt en euro-atlantisk symbiose etableres eller ej afhænger af den eksisterende politiske vilje. Intet institutionelt set-up kan erstatte politisk vilje, som i sin tur er betinget af geopolitiske grundvilkår. Imidlertid kan opretholdelsen af en symbiose, når den først er etableret, lettes af internationale institutioner.

\section{Nye institutioner?}

Der er mange institutioner, der i dag sørger for den euro-atlantiske dialog: NATO, den bilaterale USAEU dialog, OSCE, G8 og FN's Sikkerhedsråd. De to førstnævnte er direkte skræddersyet til formålet, de øvrige har andre hovedformål eller medlemslande. Bortset fra USA-EU dialogen, baseret på "New Transatlantic Agenda" fra 1995, blev alle disse institutioner etableret under den Kolde Krig, dvs. under helt andre betingelser. Det har imidlertid ikke været noget problem. Koblingen af nye formål til disse institutioner har faktisk været mere reglen end undtagelsen. Mens G7 oprindelig var helliget verdensøkonomiske spørgsmål, tackler den i dag alle mulige udfordringer, herunder terrorisme, Irak, osv.

Med så mange institutioner med snævert relaterede formål burde der være rige muligheder for atlantiske regeringsledere og embedsmænd at mødes uformelt og diskutere strategiske spørgsmål. Hvortil kommer mulighederne for bilaterale møder, ofte arrangeret i forbindelse med multilaterale sammenkomster. Alene i juni 2004, blot for at nævne et eksempel, deltog regeringslederne i et omrejsende "topmøde show" med møder i Georgia, USA (G8), Irland (USA-EU topmøde) og Tyrkiet (NATO), med en hel del overlappende emner. I denne hektiske måned var der også Bushs møde med Italiens premierminister Berlusconi i Rom, hans møde med præsident Chirac i Paris og adskillige regeringslederes møder i forbindelse med præsident Reagans begravelse og fejringen af 60-året for D-dag i Normandiet.

Set i lyset af dette overflødighedshorn af eksisterende dialogmuligheder forekommer nye institutioner ikke strengt nødvendige. Måske kunne en "frisk start", ville nogen sige, være påkrævet efter Irak, ikke mindst psykologisk. Dette undervurderer imidlertid vanskeligheden ved at bygge nye institutioner. Det er 
nemt nok at nedmontere dem. Det er imidlertid en luksus at give afkald på samarbejdsrutiner inden for eksisterende institutioner såvel som deres hovedkompetencer (forudsat at der stadig er brug for dem).

Det kan indvendes, at man kunne slippe af med noget institutionel "dødvægt" (den ubarmhjertige betegnelse i IGO-jargonen for inkompetente embedsmænd eller ineffektive afdelinger) ved at starte på en frisk med nye institutioner og nye internationale embedsmænd. Dette problem kan imidlertid løses ad anden vej jf. nedenfor. Desuden klynger stater sig, forståeligt nok, til eksisterende succeser som koldkrigsvinderne NATO og EU, illustreret ved deres mange nye ansøgerlande.

Endvidere bliver ethvert forsøg på at finde den ultimative institutionelle løsning også let en ufrugtbar søgen efter de "vises sten", der let kan splitte alliancen. Skal den splittes, fortjener den, at det sker med baggrund i noget substantielt. Sidst men ikke mindst er det næppe sandsynligt, at parterne - et USA i "krig" og et Europa i forfatningskrise - besidder det nødvendige overskud til at gå i gang med en opgave af denne art.

\section{Et reformperspektiv}

Mens der således næppe er behov for nye institutioner, er det nødvendigt med reform af de eksisterende. Om end de fleste har tilpasset sig perioden efter de Kolde Krig, synes reform at være påkrævet igen med det nye sæt udfordringer præsenteret ovenfor. Med slyngplanteopfattelsen af internationale sikkerhedsIGOer må institutionel reform basere sig på en pakkeløsning mellem de vigtigste nationale aktører. Balancen mellem nationale favoritinstitutioner må opretholdes for at reform kan vinde generel og dermed helhjertet støtte. Ellers bliver nok så fremragende reformforslag aldrig vedtaget.

I den euro-atlantiske sammenhæng er de vigtigste nationale aktører Frankrig på den ene side og USA/Storbritannien på den anden. NATO er favoritorganisationen for sidstnævnte, idet den sikrer amerikansk indflydelse i Europa og et forum, hvor USA kan entrere med sine europæiske partnere enkeltvis i stedet for som en blok. Med de franske ambitioner om et "uafhængigt Europa" ses EU's fælles udenrigs-, sikkerheds- og forsvarspolitik som spiren hertil. Det bilaterale forhold EU-USA er det naturlige forum for atlantisk dialog, fordi Europa her taler med én stemme. Set fra Paris er NATO i for høj grad USA's redskab. Andre europæiske lande kan, mere eller mindre klart, klassificeres som enten atlantister, der prioriterer NATO-kanalen, eller kontinentalister, der prioriterer EU-USA kanalen. Ikke mindst de østeuropæiske lande foretrækker USA-dominans inden for NATO frem for tysk og 
fransk dominans i EU inden for et bilateralt EU-USA set-up.

For at være balanceret må enhver reform samtidig styrke og forbedre EU-USA kanalen og NATO-kanalen. De er forbundne kar. G8 ville naturligvis være en mulighed, eftersom den er "neutral" i forhold til den fransk-amerikanske konkurrence. Skønt den har udviklet sig fra et rent $\varnothing$ konomisk fokus til et bredere register, er dens ulempe, at for mange ikke-stormagter udelukkes, hvorved legitimiteten begrænses. OSCE, traditionelt Ruslands favorit-organisation, kan naturligvis også reformeres, men den er til nærværende formål for tæt knyttet til det ex-sovjetiske territorium. Ligeså lidt som G8 er den specialiseret i atlantiske relationer. FN's Sikkerhedsråd beskæftiger sig med presserende kriser rundt omkring i verden og derfor ikke atlantiske relationer som sådan. Det kan være et udstillingsvindue for euro-atlantisk uenighed og EUsplittelse, som under Irak-krisen, men det er ikke stedet, hvor man finder euro-atlantiske løsninger.

\section{NATO reform}

Hvad der står tilbage her er derfor at identificere reformer af hhv. NATO og EU-USA-kanalerne, der i store træk kan afbalancere hinanden. Desuagtet er der naturligvis grund til at bifalde, hvis strategiske diskussioner i de øvrige fora skulle føre til atlantiske landvindinger.
NATOs kernekompetence er ledelse af multinationale militære styrker inden for integrerede strukturer. Til dette hører interoperabilitet mellem nationale styrker, fælles procedurer og våbenstandarisering, m.v. Denne kernekompetence kan tilbydes til forskellige "markeder" såsom forsvar af en medlemsstat, krisestyring, fredsbevarelse eller fredsskabelse. En effektiv styrkeledelse er nødvendig for, at disse markeder skal kunne fungere. Der er ikke nogen anden europæisk "skole" end NATO, hvor denne kompetence kan læres. Den er endvidere næsten umulig at kopiere på grund af de enorme pengebeløb, det ville kræve at bygge en tilsvarende militær organisation.

Ved at udfordringen er skiftet fra den sovjetiske trussel til "ustabilitet og kaos" i det euro-atlantiske område, i stigende grad med terrorisme som ingrediens, er kernekompetencen forblevet væsentlig, skønt den specifikke type af efterspurgte militære operationer har ændret sig. Evnen til at deployere og opretholde begrænsede styrker langt væk er nu vigtigere end at kunne føre store hærenheder. Endvidere er projektion af stabilitet og demokrati blevet en vigtig kompetence, udført med særlig succes i forhold til de potentielle medlemslande. EU har en tilsvarende kompetence, der imidlertid fungerer langsommere, fordi håb om EU-medlemskab for mange lande er et mere langsigtet projekt - 
hvis det overhovedet er realistisk.

NATO er vokset fra 16 til 26 medlemslande gennem udvidelserne i 1999 og 2004, og yderligere udvidelser kan forventes. Med NATOs formelle beslutningsmåde har dette betydet en tilføjelse af mange potentielle veto-magter. Udvidelserne medfører også større forskellighed i vurderingen af sikkerhedstrusler; hvert medlem er nu engang mest optaget af sit eget nærområde, og "trusler/incitamenter aftager med afstand" ifølge en velkendt geopolitisk indsigt. Hvis hertil føjes medlemmernes historiske geopolitiske erfaringer, vil forskellighederne tiltage yderligere. Mens fx begivenheder i Nordafrika eller på Balkan for Norge eller de baltiske lande ligger hinsides deres sikkerhedsbekymringer, synes måske Spanien eller Canada, at de baltiske landes frygt for et styrket Rusland grænser til hysteri.

For at opretholde sammenhængskraft og manøvreduelighed i NATO under disse ændrede betingelser har bl.a. Christoph Bertram (Stiftung Wissenschaft und Politik, Berlin) foreslået at oprette en "styringskomité”. Forslaget indebærer en formalisering af 1990'ernes diskrete "firebande" (de amerikanske, tyske, britiske og franske NATO-ambassadører, som holdt en art - officielt benægtede - rådsforberedende teselskaber), men vel at mærke med tilføjelse af Italien, Polen, Spanien og EU's udenrigspolitiske koordinator! I tillæg til disse permanente medlemmer føjes en håndfuld roterende medlemmer, mens generalsekretæren leder møderne. Til denne struktur føjes nogle regionale råd omhandlende "sekundære regioner", det være sig Afrika, Latinamerika eller Fjernøsten. USA som den eneste supermagt skal være til stede i dem alle, sammen med dem der måtte signalere en interesse i at deltage. Medlemmerne af de regionale råd forventes så, hvis de kan enes indbyrdes om nødvendig handlen, at drive lobby-virksomhed i styringskomitéen for at vinde generel støtte og dermed NATOs blå stempel.

Et forslag som dette, med visse mindelser om et stormagtsdirektorat, ville sandsynligvis blive mødt med nogen skepsis blandt ikke-stormagterne. Imidlertid er det sandsynligt, at status quo vil føre til lignende grupperinger, hvis NATO overhovedet skal forblive manøvredygtigt. Gennemsigtigheden ved formelle grupperinger vil være at foretrække frem for en sådan udvikling.

Et beslægtet spørgsmål er, hvorvidt beslutninger skal tages ved konsensus i Det Nordatlantiske Råd (dvs. at alle medlemmer har vetoret). Der kunne måske argumenteres for, at effekten af ti nye potentielle veto-magter kun kunne modvirkes gennem at afskaffe vetoretten, helt eller delvist. Det er imidlertid næppe muligt at kombinere den ovenfor beskrevne styringskomité med et så symbolsk vigtigt skridt; det ville opfattes som et dobbelt slag 
mod ikke-stormagterne. Af samme grund kunne en afskaffelse af vetoretten give problemer i forhold til de offentlige opinioner i flere lande - problemer som ville være ude af proportion med de vundne fordele. Under alle omstændigheder vil "fodnoter" i praksis være det fremherskende. Disse tilfører den fornødne fleksibilitet uden at føre til institutionel lammelse. At tillade vetoer er derfor en billig indrømmelse til den nationale suverænitet.

Forslag til at styrke generalsekretæren og hans sekretariat er fremkommet med jæune mellemrum i løbet af NATOs levetid. Generalsekretæren har både en administrativ funktion, at lede sekretariatet, og en politisk. Indeholdt i sidstnævnte er brobygning mellem medlemsstater, herunder både atlantisk brobygning og mellem et rådsflertal og skeptiske lande. En klassisk recept for at forbedre den politiske funktion er at vælge en generalsekretær med høj forhåndsstatus blandt medlemmerne. Dette kan sikres bl.a. ved at vælge vedkommende blandt forhenværende stats-, udenrigs- eller forsvarsministre, hvis ord har vægt $\mathrm{i}$ kredsen af tidligere kolleger. Imidlertid tenderer mange andre hensyn at indgå på dette punkt.

Hvad angår sekretariatet vil bedre karrieremuligheder for NATOs internationale embedsmænd med stor sandsynlighed tiltrække en højere kvalificeret stab og også øge prestigen ved at være international em- bedsmand. Ved også at afskaffe det nationale kvotasystem ville der være en mulighed for, i et længere tidsperspektiv, at slippe af med den omtalte "dødvægt".

Bortset fra navnlig infrastrukturomkostningerne og den International Stabs lønninger har NATO ikke noget fællesbudget. Et fælles budget for nationale styrker har altid været et følsomt emne, fordi det ses som en trussel mod den nationale suverænitet. Det er blevet foreslået, at NATOs forsvarsplanlægning, i stedet for at dække medlemslandenes samlede styrker, burde koncentrere sig om de styrker, som har sandsynlighed for at blive brugt i fælles operationer - og så nærmest ignorere resten. Dette kunne måske være realistisk. Med et fælles budget vil afståen fra deltagelse i en bestemt militær operation blive mere acceptabelt for dem, der "tager slæbet", fordi alle bidrager finansielt. Dette vil lette byrdefordelingen og forhåbentlig neddysse "free-rider" diskussionen, som traditionelt har plaget den atlantiske dialog.

\section{"Task expansion"}

"Task expansion" (opgave-udvidelse) har været en løsning i tidligere NATO-kriser som $\mathrm{fx}$ ved afslutningen af den Kolde Krig. Det kan forstås både i funktionel og geografisk forstand. Mens NATO tidligere er gået "out-of-area", er emnet i dag snarere, om NATO skal tillægges et 
globalt ansvarsområde. Dette støttes praktisk taget af alle amerikanske tænketanke og også nogle europæiske; de undervurderer det geopolitiske princip om, at "magt og incitament aftager med afstand" og at kun supermagten i nogen grad kan overskride dette.

Det skal indrømmes, at mange europæiske statslederes "lip service" giver indtryk af det modsatte; imidlertid bærer deres staters faktiske gerninger og kapabiliteter vidnesbyrd om en begrænset radius. Europæiske stater er ikke så engagerede som USA i fx Nordkoreas atomtrussel, Kinas stigende magt i Asien (modsat dets økonomiske styrke) eller sydamerikansk politik (undtagen Spanien og Portugal). At påtage sig et globalt ansvarsområde ville derfor kun skabe falske forventninger, som snart ville blive bittert skuffede og dermed måske sætte NATOs fremtidige troværdighed og eksistens på spil.

Funktionel "task expansion" kunne omfatte generel udenrigspolitik, for eksempel, uden forbindelse med specifik militær indsats. Dette ville væsentligst omfatte strategiske relationer med Rusland, Mellemøsten, forholdet til Iran, osv. Koblet til geografisk "task expansion" ville det også omfatte forholdet til Kina, for eksempel. For imidlertid ikke at blande det sammen med og komme til at underminere EU's fælles udenrigspolitik (FUSPen), skulle denne sidstnævnte koordination af syns- punkter udføres først. Dernæst ville følge en europæisk-amerikansk diskussion inden for rammerne af NATO. En sådan forhåndsafstemning af europæiske synspunkter ville stride mod den amerikanske NATO filosofi "no European pre-cooking in NATO!". Alt i alt ville en inkorporering af generel udenrigspolitik i NATO derfor næppe kunne undgå at støde ind i ømme punkter hos enten europæerne eller amerikanerne.

Funktionel "task expansion" kunne også indebære post-konflikt opgaver som udvikling af civilsamfundet, polititræning, økonomisk genopbygning eller politisk reform. Når der imidlertid fra EU-staternes side er investeret så meget i opbygningen af EU's kapacitet på disse områder, er det usandsynligt, at de vil investere i tilsvarende NATO-kapaciteter. Som modstykke til Berlin+ kunne NATO i stedet låne sådan "soft power" fra EU. Alt i alt synes de typer af "task expansion", som er overvejet her, næppe at være realistiske.

\section{Reform af EU-USA topmøderne}

Som vi husker, er NATO- og EU-udvidelserne samt behovet for uformel strategisk dialog hovedtilskyndelserne bag atlantisk institutionel reform. Reformbehovet gælder også EUUSA dialogen. Med kulmination i årlige topmøder er denne dialog som nævnt traktat-bundet, men mangler en organisationsmæssig infrastruktur. EU-USA er en besynder- 
lig relation, simpelthen fordi EU er en unik enhed: noget midt imellem en føderation og en IGO. Den kan betragtes som en rimeligt koherent aktør i emner som handel og miljø, men ikke i udenrigs- og sikkerhedspolitik. Jo mere "high politics" der er på spil, desto mindre koherent optræder EU.

Der synes at herske en vis utilfredshed med EU-USA topmøderne. Ifølge den franske USA ambassadør er de elendige: "hver gang vi mødes til disse såkaldte topmøder, diskuterer vi bananer og stål. Vi burde diskutere strategi". Den fhv. danske ambassadør i Washington, også med ønsket om en strategisk dialog, taler diplomatisk om en "omstændelig måde at føre dialog på”. Møderne domineres af en bureaukratidrevet dagsorden. Selvom der underskrives erklæringer om økonomiske emner, HIV-aids, Mellemøsten, Irak, Sudan, masseødelæggelsesvåben eller FNreform, føres der ingen substantielle diskussioner om disse emner ved topmøderne (som varer ca. 3 timer).

At sammenligne de europæiske 2004 og 2005 topmødedeltagere er instruktivt på mere end én måde. Deltagere i juni 2004 i Dublin var Romano Prodi (kommissionsformand), Bertie Ahern (ministerrådsformand og irsk premierminister), Loyola de Palacio (Kommissionens næstformand), Chris Patten (kommissær for eksterne relationer), Pascal Lamy (handelskommissær), Ján Figel (Commissioner for Enterprise
Policy), Javier Solana (udenrigspolitisk koordinator), Brian Cowen (irsk udenrigsminister) og Mary Harney (irsk viceudenrigsminister). Europæiske deltagere i juni 2005 topmødet i Washington var José Manuel Barroso (kommissionsformand), Jean-Claude Juncker (ministerrådsformand og Luxembourgs premierminister), Günter Verheugen (Kommissionens næstformand), Benita Ferrero-Waldner (kommissær for eksterne relationer og europæisk naboskabspolitik), Peter Mandelson (handelskommissær), Jean Asselborn (Luxembourgs udenrigsminister), og Javier Solana (udenrigspolitisk koordinator).

Mens den amerikanske side ved begge lejligheder var repræsenteret med nogenlunde samme hold, anført af præsident Bush, herskede diskontinuiteten på den europæiske side. Som det skulle fremgå af ovenstående, var kun Solana til stede ved begge møder. Styrken ved disse topmøder er ikke just at dyrke personlige relationer (skønt Kommissionsudskiftningen mellem de to topmøder gør eksemplet lidt unfair).

En anden vigtig kendsgerning er fraværet af de tre store (Tyskland, Frankrig og Storbritannien). Teknisk set er ethvert formandskab naturligvis i stand til at repræsentere EU-synspunkter ved at lade præfabrikerede erklæringer blive læst op og underskrive de relevante dokumenter. Når det imidlertid drejer sig om strategiske og sikkerhedspoliti- 
ske emner, og især de uformelle diskussioner om dem, er EU's mangel på koherens og troværdighed et alvorligt problem. Problemet er m.a.o. ikke irsk, luxembourgsk eller anden småstatsinkompetence; det ligger i EU's historisk fremvoksede konstruktion.

\section{Topmødereform}

For at fremme atlantisk strategisk dialog har Charles Grant fra Centre for European Reform i London foreslået en topmødereform. Den europæiske side bør altid omfatte lederne for Tyskland, Frankrig, Storbritannien, nogle få roterende ikke-stormagter og Kommissionen samt den udenrigspolitiske koordinator. Kaminpassiarer eller tilsvarende uformelle sammenkomster uden efterfølgende pressekonference bør foretrækkes. Endvidere skal "kontaktgrupper" diskutere særlige emner, hvor de involverede lande, hvad enten de er stormagter eller ej, skal deltage. Man kan antage, at Kommissionen vil tage føringen i handels-, miljø-, eller andre "low politics" forhandlinger, mens staterne, især de store, vil oplade deres røst i udenrigs- og sikkerhedspolitik, suppleret af den udenrigspolitiske koordinator.

Grants forslag er et godt svar på udvidelsesudfordringen og giver et realistisk forum for den nødvendige strategiske dialog. Det anerkender, at EU er meget mindre end en føde- ration, men også det faktum at medlemmerne er ulige hvad angår magt og indflydelse. Forslaget forudsætter velsagtens, at FUSP'en og ESFP'en er organiseret efter samme struktur.

Formelle beslutninger bør imidlertid stadig tages af de fulde FUSP og ESFP råd. Af samme grund som i NATO-sammenhængen - frygt for et stormagtsdirektorat - bør medlemmernes vetoret bevares så vel som muligheden for at stå udenfor. Grants forslag er i store træk analogt til NATO-reformen diskuteret ovenfor, skønt han betragter NATO som mindre væsentlig og øjensynligt uden behov for reform. I tillæg til Grants forslag bør topmøde-hyppigheden fordobles, så møderne holdes to gange om året (som EU-Rusland topmøderne). Blandt andre fordele ville dette øge de personlige kontinuiteter.

Forslagene i den nedfrosne EUforfatningstraktat vedrørende et permanent formandskab og fusioneringen af posterne som kommissær for eksterne relationer og udenrigspolitisk koordinator til en post som EU-udenrigsminister kunne med fordel tilføjes. Udenrigsministeren ville ikke kun være "sælger" for EU's udenrigspolitik (som koordinatoren i dag), men også bidrage væsentlig til den med dagsordenssættende kompetence. Oprettelsen af en EUudenrigstjeneste ville bidrage til en EU-udenrigspolitisk "hukommelse". Disse forslag passer fint sammen med Grants. De ville givetvis forenk- 
le EU-USA dialogen, såvel som dialog med andre stater, ved i nogen grad at øge EU's kontinuitet og troværdighed.

Alt i alt reparerer dette på ingen måde EU's grundlæggende svagheder i udenrigs- og sikkerhedspolitik: dets konservatisme (laveste fællesnævner tilgang), dets træghed (tiden det tager at træffe beslutninger) og dets begrænsede troværdighed i forhold til stormagterne (grundet de forskellige holdninger til USA, Rusland, tyrkisk medlemskab, osv.). Imidlertid vil forslagene lette EU's eksterne dialog ved deres anerkendelse af EU's indbyggede svagheder og gøren det bedste ud af dem.

Der blev ovenfor argumenteret for, at mulig NATO "task expansion" burde holde sig væk fra den generelle udenrigspolitik. De store politisk-strategiske spørgsmål, hvordan det atlantiske fællesskab kan påvirke Rusland, Kina, Iran, Afrika eller den mellemøstlige fredsproces bør til gengæld afklares på EU-USA topmøder, naturligvis efter forudgående behandling i FUSPen.

Med en geografisk ubegrænset dagsorden er der imidlertid en åbenbar risiko for amerikanske skuffelser med dets europæiske partner(e). Med den udbredte amerikanske negligering, både blandt akademikere og praktikere, af det næunte princip om at "magt og incitament aftager med afstand" vil der fortsat finde en overvurdering sted af EU's og dens medlemsstaters geografiske rækkevidde og engagement. Hvis Europa ikke er globalt orienteret, beskyldes det for at være "indadskuende" eller "navlebeskuende". Med denne ugyldige dikotomi og enten/eller tænkning underspilles Europas store naboskab, fra Barentshavet til Vestafrika, som et ressource-krævende indsatsområde.

Forskellig geografisk radius vil formentlig forblive en kilde til atlantisk konflikt. Det vil formentlig blive sat på spidsen og belyst med Kinas opstigen til stormagt. Det er fx blevet hævdet af Grant, at de atlantiske spændinger omkring EU's mulige hævelse af sin våbenembargo mod Kina kunne have været undgået med en reformeret dialog. Denne optimisme deles ikke her, eftersom uenigheden er ægte - baseret på forskellige geografiske indflydelsessfærer. Det er i hvert fald ikke indlysende, at overtalelse alene ville have løst noget. Kun hvis EU var blevet tilbudt "noget for noget", kunne uenigheden måske være blevet bortvejret.

\section{Reformforslag: en opsummering}

Mega-udvidelserne af EU og NATO samt behovet for uformel strategisk dialog nødvendigg ør atlantisk institutionel reform. (En diskussion af reformforslagene i forhold til danske geopolitiske interesser findes i den tilgrundliggende rapport [Hans Mouritzen, Atlantic Reform. A Euro-Atlantic and a Danish Perspective]). Der 
er imidlertid ikke behov for nye atlantiske institutioner. Derimod er der behov for tilpasning af de eksisterende. Den bør være politisk balanceret i forhold til hhv. USA/Storbritannien og Frankrig. Dette indebærer, at de to hovedkanaler for atlantisk samarbejde, NATO og EUUSA dialogen, begge reformeres grundlæggende og nogenlunde analogt.

En styringskomité, bestående af USA, Storbritannien, Frankrig, Tyskland, Spanien, Polen og en håndfuld roterende medlemmer samt EU's udenrigspolitiske koordinator, indføres i NATO for at forberede møderne i Det Nordatlantiske Råd. Beslutningsproceduren i Rådet skal stadig være konsensus. NATOs generalsekretær og den Internationale Stab bør styrkes gennem en karrieretjeneste og afskaffelsen af kvotesystemet Et fælles budget bør gælde de nationale styrker, der bruges i fællesoperationer. NATO "task expansion" bør undgås, såvel funktionelt som geografisk.

EU-USA topmøderne bør give mulighed for uformel strategisk dia$\log$ i stedet for at følge en bureaukrati-drevet dagsorden. De store strategiske spørgsmål vedrørende forholdet til Rusland, Kina, Mellemøsten, Afrika, osv. bør afklares her. EU-siden bør altid omfatte lederne for Storbritannien, Frankrig, Tysk- land, nogle få roterende ikke-stormagter, Kommissionen og den udenrigspolitiske koordinator. Topmødehyppigheden bør fordobles, så topmøderne holdes to gange årligt. Mens EU endvidere bør fortsætte med at låne "hard power" fra NATO (Berlin+), bør NATO tilsvarende låne "soft power" fra EU.

Af hensyn til indbyrdes tillid og gennemsigtighed er det vigtigt, at de to atlantiske kanaler og deres institutioner har observationsposter hos hinanden. EU's udenrigsminister (eller koordinator) bør som nævnt have en sådan post i den foreslåede styringskommitté i NATO, mens NATOs generalsekretær bør inviteres med til EU-USA dialogens kaminpassiarer.

Denne artikel bygger på en mere omfattende engelsksproget rapport (Atlantic Reform. A Euro-Atlantic and a Danish Perspective, DIIS, april 2006) om atlantisk institutionel reform. For så vidt angår omfattende litteraturhenvisning og dokumentation henvises til denne rapport. Arbejdet har voret finansieret af Forsvarsministeriet og bistået af Udenrigsministeriet. De fremførte synspunkter står naturligvis for forfatterens egen regning

Hans Mouritzen er dr.scient.pol. og seniorforsker ved DIIS 